\title{
Informational, Educational, and Scientific Values of Environmental Data Interactive Visualizations**
}

\begin{abstract}
Various programmatic techniques and tools are more and more frequently being used for the interactive visualization of data, especially environmental data. Their prevalence and domain of their use in environmental management as well as the promotion and popularization of scientific survey results have increased successively. Chosen examples of applications of environmental data interactive visualizations were presented in the paper, their advantages and disadvantages were discussed, and some of the most-popular techniques and tools used in their creation were listed. In conclusion, it was pointed out that data visualizations are being applied more and more in the natural and technical sciences. Moreover, it was noticed that environmental data visualizations can influence the efficiency of environmental management, and the repeatedly reiterated and multi-sourced transmission of data can publicize environmental problems as well as affect the ecological awareness of individuals or social groups.
\end{abstract}

Keywords: data interactive charts and diagrams, internet cartography, environmental management, popularization of science, environmental computer science

* University of Agriculture in Krakow, Faculty of Environmental Engineering and Land Surveying, Department of Land Management and Landscape Architecture, Krakow, Poland

** The surveys were financed from the Personal Scholarship Fund for academics of the Hugo Kołłataj University of Agriculture in Krakow 


\section{Introduction}

Phenomena that occur in the surrounding space are more and more frequently presented by means of graphics and images, which have gradually replaced the textual description [36]. Graphic vision of the figures has deep roots. They date back to the history of topic cartography, statistical graphics and data visualization which coexist and complement each other [18].

Visualization is a form of communication that uses an image as a tool of data presentation and connections between them. This tool supplements analytical activities i.e. revealing various interactions. It provides resources which make easier or sometimes allow to observe relations hidden in numbers - relationships, trends and principles, rules, structures, symmetries, similarities and anomalies which would be difficult to reveal by means of analytical methods [11]. It is often a culmination of project process preceded by data gaining and processing. Visualization connects technical abilities of data processing, analyzing, and interpretation with rules of aesthetics, innovative design, and interaction.

The aim of the paper is to prove the informative, educational, and scientific values of the interactive visualizations of environmental data from the point of view of widely understood environmental management. Attention in the surveys was also paid to the growing significance of visualization in decision-making processes, its marketing values, as well as its usage in promotion and popularization of scientific research.

The surveys' authors suggest that the visualization of environmental data provided in a browser's window can arouse interest in environmental protection and development problems, it can stimulate the growth of the recipients' ecological awareness and can also be a helpful tool in decision-making processes as well as analyses and studies from the range of planning and spatial management.

\section{Form of Interactive Visualization of Environmental Data}

There are many various computer techniques and tools accessible on the Internet that allow us to create attractive and interactive data visualizations. Access to the chosen ones is not limited, whereas using some others requires payment (subscription, single payment, etc.). Public computer techniques and tools are most often used by independent users of the Internet who create communities around various citizens' projects, often environmental ones. They represent the trend of transformations connected with using network resources (produsage) [8]. This trend involves active users that change from passive ones into creators of content made accessible on the Internet (producers) [4]. Environmental data visualizations created in the spirit of 'a producer' come into being spontaneous, often as a result of the strong 
emotions that occur in the group of citizens who are aware of environmental problems of various scales.

One of new and more-often-used research methods of surveying and describing the natural environment is data journalism, which joins the competences of scientists, programmers, and analysts as well as graphic designers. Interdisciplinary teams more often use internet techniques and tools to present the various risks and dependencies that take place in the natural environment.

An interactive visualization also allows us to present global problems without the influence of international corporations. The independence of presentations prepared in such a way is possible thanks to, inter alia, numerous applications (usually network ones) that allow users without expert knowledge and additional software (and also in an automated way) to create and publish attractive data visualizations as well as maps. All of this as well as common access to open data resources and geo-information tools have given rise to internet cartography and formed 'Volunteered Geographic Information' (VGI) [20].

Environmental data visualization in a browser window usually takes one of two forms: a chart or diagram (simple or advanced, prepared in the form of a dashboard or map). They can take the form of computer statistical graphics (rasters) or dynamic interactive applications that allow users to shape the form of the data and range of the presentation (Fig. 1). Moreover, the considerable potential of environmental data presentations is hidden in infographics [23]. This was observed by He and co-authors [21], who presented the concept of a traditional topic map connected with infographics called 'geo-infographics.' According to researchers, they considerably improve spatial data representations.

Interactive visualizations of environmental data can take less- or more-advanced forms. Advanced interactivity carries some added value in the form of opportunity to perform data analysis by a user, but often within a range that was made possible by the visualization's creator. Advantages of environmental data visualization interactivity on the Internet are demonstrated and accented by Andrienko et al. [2] as well as Roth and MacEachren [35].

Complex visualizations usually need the use of expert techniques and tools; e.g., Application Programming Interfaces (API). A common user can create data visualization by means of a graphical user interface (GUI), one of numerous tools whose service consists of defining certain parameters of visualization by means of, inter alia, check boxes or drop-down lists. A visualization prepared in such a way can comprise a component (extension) of an Internet site or an independent website.

The growing amount of data somewhat forces the development of new forms of its presentation. New database technologies (in connection with new web technologies) can be the key to reducing the costs of creating data visualizations as well as enable them to be used not only as a culmination of surveys (result presentation) but also as a research tool [17]. 


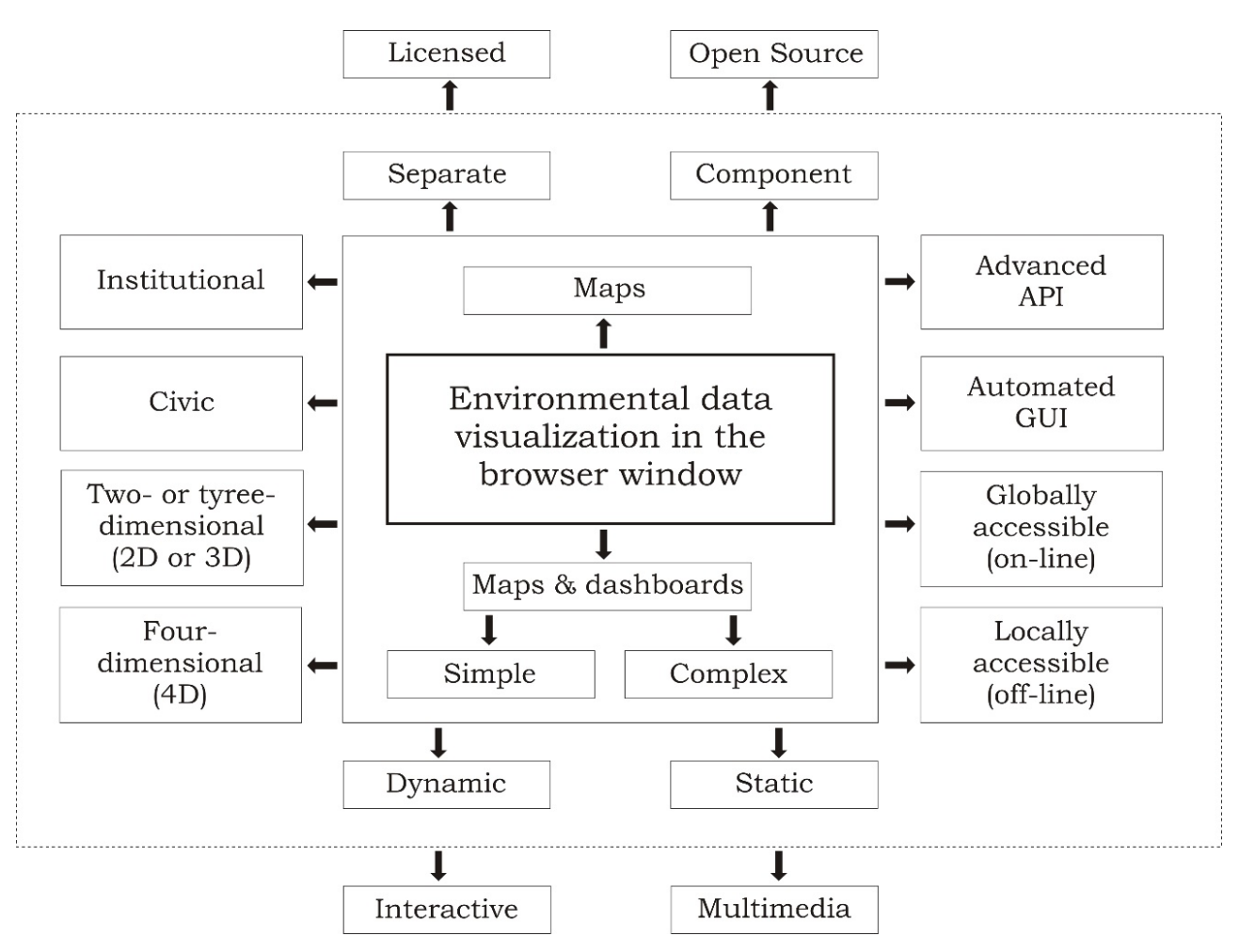

Fig. 1. Characteristics of environmental data visualization in browser window

\section{Chosen Examples of Environmental Data Visualizations}

Visualization allows us to present events and survey results that are usually closely related to definite time and space; it can be an effective tool that helps us analyze a myriad of environmental data, both at the stage of the interpretation of events and in drawing conclusions.

In scientific surveys and data collecting, processing and visualization in particular, techniques and tools made accessible free of charge are being used more often. One of them is Google Fusion Tables (GFT), the tool that allows us to prepare an interactive presentation of data, objects, or events in an automated way, both in the form of interactive charts and diagrams as well as maps [19]. Yue, Jiang, and $\mathrm{Hu}$ [41] use them in their research as the presentation platform of soil humidity measurements received directly from detectors deployed in fields. In their work, the researchers presented how to use Google Fusion Tables to illustrate the data of the state of natural environment and make it public. 
The service of data visualization in the form of a heatmap made accessible by GFT was used by Devarakonda et al. [14]. By means of this, researchers created an interactive presentation of the measurements of air pollutants that occur near the NJ Turnpike (New Jersey Turnpike, New Jersey, USA). In turn, Kulawiak et al. [26] presented a web system of geographic information (GIS Web) for existing oil spill monitoring and forecasting service.

Using GFT in data visualization (as well as its opportunity to spread the tool's default functionalities) was also presented by De Paor et al. [13]. In turn, Bowie, Millward, and Bhagat [7] used GFT and Table Fusion API to create a data management system in the form of an interactive network platform, the aim of which was to present plants growing on the grounds of the Ryerson University campus in Toronto. The assumption of the researchers was to enable users to search the trees on a Google map according to their species, diameter, height, and location. This tool was used for a similar purpose by Lee, $\mathrm{Yu}$, and Chien [27] while preparing an interactive map of the vegetation that grows on the Chung Hua University campus in Hsinchu City, Taiwan.

Moreover, environmental data is also presented in the form of interactive charts and diagrams that are made by means of various project techniques and tools and that take the form of a different figure: from the components of websites to independent web applications $[6,10,16,32]$.

Environmental data visualization also takes the three-dimensional form, which is more often used in providing scientific and environmental information involving the receiver's perception to a higher extent than classic internet maps. Realism and perspective projections bring new cognitive values, but they also cause new reactions (including emotional ones) as well as doubts as regards the pictures' credibility and bias of their interpretation [37]. Lindquist, Lange, and Kang [28] proved that connecting sounds with 3D visualization significantly increases the realism of natural environment virtual presentations and changes their perception. Paar [34] surveyed the use of 3D modeling technologies in the range of landscape and spatial planning visualization by private landscape planning consultancies, freelance landscape architects, and public authorities responsible for spatial planning and protection of the environment in Germany. $\mathrm{Xu}$ and Coors [39] presented three-dimensional visualizations that can be applied in city spatial planning, taking the Stuttgart Region of the state of Baden-Württemberg in southern Germany as an example. In turn, Velasco et al. [38] showed the possibility of using 3D visualization in modeling hydro-geological phenomena on the basis of geological data collected as spatial information system GIS, taking surveys of the Besòs Delta in the metropolitan area of Barcelona on the coast of the Mediterranean Sea in Spain as an example. In turn, Ames et al. [1] present a web application that allows users to manage hydrological data as well as its analysis and visualization on the example of the Bear River Watershed region in the US state of Idaho. 
In these examples, the scientists were using the advantages of cloud technologies and presented an integrated approach - using many components and various techniques and tools in order to achieve the final effect in the form of environmental data visualization in a browser window.

Directly from the scientific advantages of environmental data visualizations comes their informative cognitive value, which can be effectively used in the process of making decisions that especially concern environment protection and shaping as well as environmental management. Meitner et al. [31] presented the use of data visualization in forest management. They pointed out that environmental data visualization can significantly improve environmental management and affect forest management efficiency. Bryan [9] presented the usefulness of spatial information systems and data visualizations in environmental management and spatial planning. In turn, Avouris and Page [3] showed the role of applied environmental informatics as well as techniques of data processing and visualization in environmental management.

Therefore, environmental data visualization can be helpful in effective and rational space management as well as making strategic decisions. However, it requires knowledge of computer techniques and tools as well as tasks directly related to environmental management $[12,22,33]$. Interestingly, environmental data visualization does not have to give explicit and proper answers. It can make a kind of 'informative environment' that allows us to explore a presented issue and perform our own analyses, thanks to which recipients are able to reach a conclusion on their own. In this case, the research work is not based on the verification of hypotheses by means of collected data but on the attempt 'to discover' some phenomena, dependencies, or trends in large data sets thanks to the use of various analytical methods, including those that consist in visualization [30].

\section{Chosen Computer Techniques and Tools That Enable Data Visualization in Browser Window}

Basically, environmental data visualization can be prepared in three ways: by using web applications created in the architecture client-server, by means of programmatic techniques (i.e., API or JavaScript libraries), or by using software of a desktop type, installed on the computer's hard drive. Techniques and tools that provide their forming are usually complementary and compatible, and they can be used together. This is due to the fact that the final effect of the works is data visualization prepared in a form that is possible to be implemented in the structure of a hypertext document. It is some standard that reduces all programmatic techniques and tools to a common denominator. So, a website can present data visualizations prepared in various formats (i.e., Adobe Flash, SVG, JavaScript) and forms (complex managerial dashboards that join interactive data charts and diagrams with the phenomena presentation on a map). It is then defined as a mashup service [5, 29, 40]. 
Web applications started in a browser window allow us to create data visualizations by means of a graphic interface mainly in an automated way. Diverse code generators and map creators (i.e., amCharts JavaScript Maps) can be classified there. Moreover, they usually allow us to create visualizations in a limited way, narrowed only to the creator's possibilities provided by its author. Greater working freedom is provided by API programmatic interfaces (programmatic techniques); i.e., Google Charts Visualization API, by means of which data visualization on a map [24, 25] or complex managerial dashboard can be created [15]. The Fusion Tables API programmatic interface, which allows us to create advanced data presentations both in the form of charts and diagrams as well as in spatial reference, is equally popular.

There are many tools available on the Internet that enable data visualization. They are usually made accessible free of charge, but their use in commercial projects may be limited. Google tools (including Google Charts and Google Fusion Tables) can be classified as most-common. Libraries JavaScript - Leaflet or D3 (Data-Driven Documents) and also amCharts, RGraph or Fusion Tables (which allow us to create, inter alia, interactive charts and diagrams) are not less popular.

Charts and diagrams can be generated in a browser window in various technologies starting from SVG graphics (Scalable Vector Graphics) and finishing with Adobe Flash animations. On the other hand, GIS systems of spatial information - by means of which a database with spatial respect can be prepared - are commonly used. This, in turn, can be the basis for an internet application or an interactive visualization.

\section{Conclusions}

The area of use and data visualization prevalence in environmental management are increasing. The chosen ones (along with their advantages and disadvantages) and those of the most-popular globally computer techniques and tools that allow us to create them were presented in the paper.

Internet applications and various environmental data visualizations support the decisive process connected with solving problems from the range of environment protection and development, allowing us to make an inventory of natural resources and infrastructure as well as model the processes that occur in the environment so that they simplify making decisions in the range of its protection and development. They have socio-informational function as well through the properly drawn-up transfer of information made accessible on the Internet by means of map services, websites, topic portals, and others (or on digital data carriers). Moreover, they provide easy access to information about protected areas: maps of nature protection forms, reservations, landscape parks, areas of protected landscapes, ecological areas, nature and landscape complexes, areas of high landscape values, and others. 
Environmental data visualizations do not have to present informative values just for recipients. Creators of data visualizations made accessible on the Internet can draw information about their recipients as well as the range of their influence. The monitoring of user activity that can be carried out regardless of the visualization's form is in question here. It is worth emphasizing that the measurements are more and more accurate, and they deliver ever more information about the users. Thereby, the provider of the transfer can get increasingly reliable data about the range of its impact.

At present, we have to deal with a developing informative society. This process was initiated with widespread access to mass media (and the Internet in particular). The informative society is the one in which individuals use information intensively and are quite often formed by it. In turn, information is regarded as a product, a factor of production and strategic good. The role of information is so big that it can comprise the tool of forming opinions and tendencies not only in geo-political matters but also environmental ones.

In research practices, data visualizations are used more often in the natural and technical sciences. It results, inter alia, from the fact that, among the preferred ways of learning reality as well as information processing and acquiring, visual modality (obtaining knowledge through images, diagrams, charts, shows) dominates in most people over verbal, motor, and touch ways. However, it is worth mentioning here that charts and maps will not replace a statistical array. This is not their task. The role of various visualizations is to simplify data presentations and facilitate the acquisition of presented information. The analysis of numerical data converted into a chart or map is usually easier than numbers presented in the form of a table.

Effective environmental protection and shaping as well as sustainability are closely related to social developments understood as increases in education levels, entrepreneurship, and awareness and responsibility for the surrounding environment. Mass media plays an increasing role here, especially the Internet and diverse forms of data presentations. They provide access to spatial information, allow local communities to participate in planning process to promote tourist, natural, and economic values of regions, simplify making decisions and managing environment, and finally, they considerably support the promotion of scientific results as well as science popularization. They comprise the channel of information flow that will gradually grow in status in the light of the ever-greater prevalence of mobile devices.

It is difficult to talk about the direct influence of environmental data visualizations on environment protection and development. However, their indirect impact can be proven. This is about the phenomenon of the regular repetition of information in the form of various messages. In a colloquial language, it can be described as 'information pressure' or 'inundating with information.' The repeated, direct, multidisciplinary, and multi-source transfer of concrete information made accessible in the form of environmental data visualization can influence the awareness of individuals and social groups. This transfer can be a tool that creates habits. Information 
pressure can be directed into changing a recipient's awareness through education and pro-ecological attitude propagation. It is a specific way of computer data transferred into information that then change the recipient's awareness in the form of visualization available by means of mass media.

\section{References}

[1] Ames D.P., Horsburgh J.S., Cao Y., Kadlec J., Whiteaker T., Valentine D.: HydroDesktop: Web services-based software for hydrologic data discovery, download, visualization, and analysis. Environmental Modelling \& Software, no. 37, 2012, pp. 146-156.

[2] Andrienko G., Andrienko N., Dykes J., Kraak M.J., Robinson A., Schumann H.: GeoVisual analytics: interactivity, dynamics, and scale. Cartography and Geographic Information Science, vol. 43, no. 1, 2016, pp. 1-2. DOI: 10.1080/15230406.2016.1095006.

[3] Avouris N.M., Page B. (eds.): Environmental informatics: Methodology and applications of environmental information processing. Springer Science \& Business Media, 2013. DOI: 10.1007/978-94-017-1443-3.

[4] Benkler Y.: Coase's Penguin, or, Linux and the Nature of the Firm. Yale Law Journal, vol. 112, no. 3, 2002, pp. 369-446.

[5] Benslimane D., Dustdar S., Sheth A.: Services mashups: The new generation of web applications. IEEE Internet Computing, vol. 12, no. 5, 2008, pp. 13-15. DOI: 10.1109/MIC.2008.110.

[6] Bostock M., Ogievetsky V., Heer J.: $D^{3}$ data-driven documents. IEEE Transactions on Visualization and Computer Graphics, vol. 17, no. 12, 2011, pp. 2301-2309. DOI: 10.1109/TVCG.2011.185.

[7] Bowie G.D., Millward A.A., Bhagat N.N.: Interactive mapping of urban tree benefits using Google Fusion Tables and API technologies. Urban Forestry \& Urban Greening, vol. 13, no. 4, 2014, pp. 742-755. DOI: 10.1016/ j.ufug.2014.06.002.

[8] Bruns A.: Produsage: Towards a Broader Framework for User-Led Content Creation. [in:] Proceedings of the $6^{\text {th }}$ ACM SIGCHI Conference on Creativity \& Cognition, ACM, New York 2007, pp. 99-106. DOI: 10.1145/1254960.1254975.

[9] Bryan B.A.: Physical environmental modeling, visualization and query for supporting landscape planning decisions. Landscape and Urban Planning, vol. 65, no. 4, 2003, pp. 237-259. DOI: 10.1016/S0169-2046(03)00059-8.

[10] Bryant N., Wildfire J.: Webcharts - A Web-based Charting Library for Custom Interactive Data Visualization. Journal of Open Research Software, vol. 4, no. 1, 2016, p. 29. DOI: 10.5334/jors.127.

[11] Carswell C.M., Wickens C.D.: Information integration and the object display an interaction of task demands and display superiority. Ergonomics, vol. 30, no. 3, 1987, pp. 511-527. DOI: 10.1080/00140138708969741. 
[12] Daniel T.C.: Data visualization for decision support in environmental management. Landscape and Urban Planning, vol. 21, no. 4, 1992, pp. 261-263. DOI: 10.1016/0169-2046(92)90036-Y.

[13] De Paor D.G., Whitmeyer S.J., Marks M. Bailey J.E.: Geoscience applications of client/server scripts, Google Fusion Tables, and dynamic KML. [in:] Whitmeyer S.J. (ed.), Google Earth and Virtual Visualizations in Geoscience Education and Research, Geological Society of America Special Papers, no. 492, Geological Society of America, 2012, pp. 77-104. DOI: 10.1130/2012.2492(06).

[14] Devarakonda S., Sevusu P., Liu H., Liu R., Iftode L., Nath B.: Real-time air quality monitoring through mobile sensing in metropolitan areas. [in:] Proceedings of the $2^{\text {nd }}$ ACM SIGKDD International Workshop on Urban Computing. ACM 2013. ACM, New York, pp. 15:1-15:8. DOI: 10.1145/2505821.2505834.

[15] Doshi J., Goradia A.I., Mistry D.: A Review of Google Data Visualization Tools. International Journal of Current Engineering and Technology, vol. 4, no. 5, 2014, pp. 3134-3138.

[16] ElTayeby O., John D., Patel P., Simmerman S.: Comparative case study between D3 \& Highcharts on Lustre metadata visualization. [in:] 2013 IEEE Symposium on Large-Scale Data Analysis and Visualization (LDAV). DOI: 10.1109/ LDAV.2013.6675172.

[17] Fox P., Hendler J.: Changing the equation on scientific data visualization. Science, vol. 331, no. 6018, 2011, pp. 705-708. DOI: 10.1126/science.1197654.

[18] Friendly M.: A brief history of data visualization. [in:] Handbook of Data Visualization, Springer, Berlin - Heidelberg 2008, pp. 15-56. DOI: 10.1007/9783-540-33037-0_2.

[19] Gonzalez H., Halevy A.Y., Jensen C.S., Langen A., Madhavan J., Shapley R., Shen W, Goldberg-Kidon J.: Google fusion tables: web-centered data management and collaboration. [in:] Proceedings of the 2010 ACM SIGMOD International Conference on Management of Data, ACM, New York 2010. DOI: 10.1145/1807167.1807286.

[20] Goodchild M.F.: Citizens as sensors: the world of volunteered geography. GeoJournal, vol. 69, no. 4, 2007, pp. 211-221. DOI: 10.1007/s10708-007-9111-y.

[21] He M., Tang X., Huang Y.: To visualize spatial data using thematic maps combined with infographics. Geoinformatics, IEEE 2011, pp. 1-5. DOI: 10.1109/ GeoInformatics.2011.5980880.

[22] Kralikova R., Rovnak M., Kralik M.: Visualization of environmental data. SGEM Scientific GeoConference, no. 2, 2008, pp. 577-584.

[23] Krauss J.: Infographics: More than Words Can Say. Learning \& Leading with Technology, vol. 39, no. 5, 2012, pp. 10-14.

[24] Król K.: Data presentation on the map in Google Charts and jQuery JavaScript technologies. Geomatics, Landmanagement and Landscape, no. 2, 2016, pp. 91-106. DOI: 10.15576/GLL/2016.2.91. 
[25] Król K., Prus B.: The comparative analysis of selected interactive data presentation techniques on the example of the land use structure in the commune of Tomice. Polish Cartographical Review, vol. 48, no. 3, 2016, pp. 1-13. DOI: https://doi.org/10.1515/pcr-2016-0009.

[26] Kulawiak M., Prospathopoulos A., Perivoliotis L., Kioroglou S., Stepnowski A.: Interactive visualization of marine pollution monitoring and forecasting data via a Web-based GIS. Computers \& Geosciences, vol. 36, no. 8, 2010, pp. 1069-1080. DOI: 10.1016/j.cageo.2010.02.008.

[27] Lee M.G., Yu K.M. Chien S.T.: Visualize Field Data in Fusion Tables-Take Chung Hua University Plant Map as Example. [in:] $20147^{\text {th }}$ International Conference on Ubi-Media Computing and Workshops (UMedia 2014): Ulaanbaatar, Mongolia, 12-14 July 2014. IEEE, 2014, pp. 261-265. DOI: 10.1109/U-MEDIA.2014.71.

[28] Lindquist M., Lange E., Kang J.: From 3D landscape visualization to environmental simulation: The contribution of sound to the perception of virtual environments. Landscape and Urban Planning, no. 148, 2016, pp. 216-231. DOI: 10.1016/j.landurbplan.2015.12.017.

[29] Liu X., Hui Y., Sun W., Liang H.: Towards service composition based on mashup. [in:] 2007 IEEE Congress on Services: (SERVICES 2007): Proceedings: Salt Lake City, Utah, USA, IEEE Computer Society, 2007, pp. 332-339. DOI: 10.1109/SERVICES.2007.67.

[30] Manovich L.: The Language of New Media. MIT Press, Cambridge 2001.

[31] Meitner M.J., Sheppard S.R., Cavens D., Gandy R., Picard P., Harshaw H., Harrison D.: The multiple roles of environmental data visualization in evaluating alternative forest management strategies. Computers and Electronics in Agriculture, vol. 49, no. 1, 2005, pp. 192-205. DOI: 10.1016/j.compag.2005.03.002.

[32] Nair L.R., Shetty S.D., Shetty S.D.: Interactive visual analytics on Big Data: Tableau vs D3. js. Journal of e-Learning and Knowledge Society, vol. 12, no. 4, 2016, p. 139-150.

[33] Orland B.: Data visualization techniques in environmental management: a workshop. Landscape and Urban Planning, vol. 21, no. 4, 1992, pp. 237-239.

[34] Paar P.: Landscape visualizations: Applications and requirements of $3 D$ visualization software for environmental planning. Computers, Environment and Urban Systems, vol. 30, no. 6, 2006, pp. 815-839. DOI: 10.1016/j.compenvurbsys.2005.07.002.

[35] Roth R.E., MacEachren A.M.: Geovisual analytics and the science of interaction: an empirical interaction study. Cartography and Geographic Information Science, vol. 43, no. 1, 2016, pp. 30-54. DOI: 10.1080/ 15230406.2015.1021714.

[36] Schnettler B.: Auf dem Weg zu einer Soziologie visuellen Wissens. Sozialer Sinn, vol. 8, no. 2, pp. 189-211. 
[37] Sheppard S.R., Cizek P.: The ethics of Google Earth: Crossing thresholds from spatial data to landscape visualisation. Journal of Environmental Management, vol. 90, no. 6, 2009, pp. 2102-2117. DOI: 10.1016/j.jenvman.2007.09.012.

[38] Velasco V., Gogu R., Vázquez-Suñè E., Garriga A., Ramos E., Riera J., Alcaraz M.: The use of GIS-based 3D geological tools to improve hydrogeological models of sedimentary media in an urban environment. Environmental Earth Sciences, vol. 68, no. 8, 2013, pp. 2145-2162. DOI: 10.1007/s12665-012-1898-2.

[39] Xu Z., Coors V.: Combining system dynamics model, GIS and 3D visualization in sustainability assessment of urban residential development. Building and Environment, no. 47, 2012, pp. 272-287. DOI: 10.1016/j.buildenv.2011.07.012.

[40] Yu J., Benatallah B., Casati F., Daniel F.: Understanding mashup development. Internet Computing, vol. 12, no. 5, 2008, pp. 44-52. DOI: 10.1109/ MIC.2008.114.

[41] Yue P., Jiang L., Hu L.: Google fusion tables for managing soil moisture sensor observations. Journal of Selected Topics in Applied Earth Observations and Remote Sensing, vol. 7, no. 11, 2014, pp. 4414-4421. DOI: 10.1109/ JSTARS.2014.2353621.

\section{Informacyjna, edukacyjna i naukowa wartość interaktywnych wizualizacji danych środowiskowych}

Streszczenie: Różnorakie techniki i narzędzia programistyczne są coraz częściej stosowane do interaktywnej wizualizacji danych, w szczególności środowiskowych. Sukcesywnie zwiększa się powszechność i obszar ich zastosowań w zarządzaniu środowiskiem oraz $\mathrm{w}$ upowszechnianiu i popularyzacji wyników badań naukowych. W pracy przedstawiono wybrane przykłady zastosowań wizualizacji danych środowiskowych, omówiono ich wady i zalety, wymieniono także jedne z najpopularniejszych technik i narzędzi umożliwiających ich tworzenie. W konkluzji zwrócono uwagę, że wizualizacje danych znajdują coraz częściej zastosowanie w naukach przyrodniczych i technicznych. Ponadto zauważono, że wizualizacje danych środowiskowych mogą wpływać na efektywność zarządzania środowiskiem, a wielokrotnie ponawiany i wieloźródłowy przekaz informacji może nagłośnić problemy środowiskowe oraz wpłynąć na świadomość ekologiczną jednostek lub grup społecznych.

\section{Słowa}

kluczowe: interaktywne wykresy i diagramy, internetowa kartografia, zarządzanie środowiskiem, popularyzacja nauki, informatyka środowiskowa 